\title{
Soil Attributes in a Sierra Nevada Riparian Meadow as Influenced by Grazing
}

\author{
Robert R. Blank, ${ }^{1}$ Tony Svejcar, ${ }^{2}$ and Gregg Riegel \\ Authors are ${ }^{1}$ Soil Scientist, USDA-Agricultural Research Service, Exotic and Invasive Weed Research Unit, 920 Valley Road, \\ Reno, NV 89512; ${ }^{2}$ Rangeland Scientist, USDA-Agricultural Research Service, Eastern Oregon Agricultural Research Center, \\ 67826-A Hwy 205, Burns, OR 97720; and ${ }^{3}$ Area Ecologist, USDA-Forest Service, Central Oregon Ecology Program, Region 6, \\ Deschutes National Forest, Bend, OR 97701.
}

\begin{abstract}
Data on the effects of livestock grazing on soil nutrient availability are virtually nonexistent for meadow systems. We measured the effect of livestock grazing on soil, emphasizing soil-solution chemistry, in a Sierra Nevada riparian meadow. Treatments were livestock exclusion (begun in 1989) and grazing to leave $1000 \mathrm{~kg} \cdot \mathrm{ha}^{-1}$ of vegetation. Ceramic tension lysimeters were placed in the treatments ( 2 replicates) by landscape position (stream edge, midfloodplain, and forest edge), and by depth (approximately 0.1, 0.6, and $1.2 \mathrm{~m}$ below the soil surface). Lysimeter water was extracted twice monthly in April, May, and June of 1990 through 1993, and cations and anions were quantified. In addition, KCl-extractable $\mathrm{NO}_{3}{ }^{-}$and $\mathrm{NH}_{4}{ }^{+}$; bicarbonate-extractable ortho-P; available $\mathrm{Mn}, \mathrm{Cu}, \mathrm{Fe}$, and $\mathrm{Zn}$; and root-length density (RLD) were quantified in soils by treatment, landscape position, and soil depth in July 1991 and September 1993. RLD was not affected by grazing. Significant $(P \leq 0.05)$ treatment effects were largely limited to the forest edge. The grazed treatment had greater lysimeter-extractable $\mathrm{Na}^{+}$, $\mathrm{Ca}^{+2}, \mathrm{Mg}^{+2}$, and $\mathrm{NO}_{3}{ }^{-}$; higher $\mathrm{pH}$; and less $\mathrm{K}^{+}$and $\mathrm{NH}_{4}{ }^{+}$than the excluded treatment. Compared with corresponding excluded treatments, bicarbonate-extractable $\mathrm{P}$ was significantly greater on the grazed forest edge, and available Mn was significantly greater at the grazed stream-edge position in 1991. Extractable $\mathrm{NO}_{3}{ }^{-}$was significantly higher in the $0-25 \mathrm{~cm}$ depth increment of the grazed treatment, and available $\mathrm{Zn}$ was significantly greater on the grazed midfloodplain position in 1993. Grazing did not result in more anoxic soil conditions than the excluded treatment. Grazing effects were most pronounced at the forest edge, possibly as a result of spatial transfer of nutrients via cow urine and feces. Management goals to sustain highelevation meadows should emphasize maintenance of high RLD to sequester soil nutrients.
\end{abstract}

\section{Resumen}

Virtualmente no existen datos del efecto del pastoreo animal en la disponibilidad de nutrientes del suelo en sistemas de praderas. Medimos el efecto del apacentamiento del ganadosobre el suelo, enfatizando en la química de la solución del suelo en una pradera ribereña de la Sierra Nevada. Los tratamientos fueron, exclusión al ganado (desde 1989) y apacentamiento hasta dejar 1000 $\mathrm{kg} \cdot \mathrm{ha}^{-1}$ de vegetación. En los tratamientos se colocaron lísimetros cerámicos de tensión (dos repeticiones) en cada posición del paisaje (orilla de cauce, cauce medio y límite del bosque) y por profundidad (aproximadamente 0.1, 0.6, y $1.2 \mathrm{~m}$ bajo la superficie). El agua del lísimetro se extrajo dos veces por mes, en abril, mayo, y junio de 1990 a 1993 y se cuantificaron los aniones y cationes. Además, se cuantifico el KCl-extractable; $\mathrm{NO}_{3}{ }^{-}$y $\mathrm{NH}_{4}{ }^{+}$; ortho-P extractable con bicarbonato; $\mathrm{Mn}, \mathrm{Cu}$, $\mathrm{Fe}$, y Zn disponibles; y la densidad de la longitud raíz (RLD), estas determinaciones se realizaron por tratamiento, posición del paisaje y profundidad de suelo en julio 1991 y septiembre 1993. RLD no fue afectada por el apacentamiento. Los efectos significativos $(P \leq 0.05)$ de los tratamientos estuvieron muy limitados a la posición del paisaje de la orilla del bosque. En el tratamiento de apacentamiento la extracción de los lísimetros tuvo una mayor cantidad de $\mathrm{Na}^{+}, \mathrm{Ca}^{+2}, \mathrm{Mg}^{+2}$, y $\mathrm{NO}_{3}{ }^{-} ; \mathrm{pH}$ mas alto; y menos $\mathrm{K}^{+}$y $\mathrm{NH}_{4}{ }^{+}$que el tratamiento de exclusión al ganado. En 1991, comparado con los tratamientos de exclusión correspondientes, el P extraído con bicarbonato fue significativamente mayor en el límite del boque apacentado, y el Mn disponible fue significativamente mayor en laposición de la orilla del cauce apacentada. En 1993, a la profundidad de 0-25 cm, los $\mathrm{NO}_{3}{ }^{-}$extractables fueron significativamente mayores en los tratamientos con apacentamiento, y el $\mathrm{Zn}$ disponible fue significativamente mayor en la posición del cauce medio apacentado. En comparación con los tratamientos de exclusión, el apacentamiento no produjo condiciones de suelo más anoxicas. Los efectos del apacentamiento fueron más pronunciados en la posición de la orilla del bosque, posiblemente como resultado de una transferencia espacial de nutrientes vía orina y heces de las vacas. Las metas de manejopara sostener las praderas de alta elevación debe enfatizar el mantenimiento RLD para que puedan tomar los nutrientes del suelo.

Key Words: lysimeter, nitrate, redox potential, root-length density, soil solution, water quality

\section{INTRODUCTION}

Correspondence: Robert R. Blank, USDA-ARS, 920 Valley Road, Reno, NV 89512. Email: blank@unr.nevada.edu

Manuscript received 29 October 2004; manuscript accepted 19 February 2006.
Although relatively small in areal extent, riparian areas in the western United States are known for their high biotic diversity, water storage capacity, and primary productivity (Warner and Hendrix 1984). Riparian areas are also critically important as a biogeochemical buffer between uplands and streams (Lowrance 
Table 1. Pedon descriptions and selected soil properties from 3 floodplain positions of the Grizzly Creek meadow, north of Portola, California. $^{1}$

\begin{tabular}{|c|c|c|c|c|c|c|}
\hline Horizon & $\begin{array}{l}\text { Depth } \\
(\mathrm{cm})\end{array}$ & Texture & $\begin{array}{c}\text { CEC } \\
(\mathrm{cmol}[+] \\
\left.\mathrm{kg}^{-1}\right)\end{array}$ & $\begin{array}{c}\text { Base } \\
\text { saturation } \\
(\%)\end{array}$ & $\mathrm{pH}$ & $\begin{array}{c}\text { Organic } \\
\text { carbon } \\
\left(\mathrm{g} \cdot \mathrm{kg}^{-1}\right)\end{array}$ \\
\hline \multicolumn{7}{|c|}{ Stream edge } \\
\hline $\mathrm{Oa}$ & $0-10$ & silty clay loam & 57.3 & 32 & 4.82 & 114 \\
\hline$A$ & $10-28$ & silty clay loam & 78.5 & 21 & 5.35 & 89 \\
\hline $\mathrm{BA}$ & $28-38$ & silty clay & 54.6 & 43 & 5.52 & 40 \\
\hline Bw & $38-61$ & silty clay & 44.0 & 54 & 5.66 & 25 \\
\hline $2 \mathrm{Cg}$ & $61-79$ & silt loam & 14.1 & 42 & 6.00 & 7 \\
\hline $3 B \operatorname{tgb}$ & $79-99$ & silty clay & 46.5 & 61 & 5.73 & 10 \\
\hline $3 \mathrm{Cg}^{2}$ & $99-112+$ & silty clay loam & 28.2 & 61 & 5.89 & 6 \\
\hline \multicolumn{7}{|c|}{ Midfloodplain } \\
\hline Oa & $0-10$ & silt loam & 59.8 & 32 & 5.00 & 155 \\
\hline$A$ & $10-20$ & clay & 55.2 & 42 & 5.29 & 56 \\
\hline$A B$ & 20-28 & clay & 43.5 & 55 & 5.39 & 30 \\
\hline $\mathrm{Bw}$ & $28-46$ & silty clay & 41.5 & 54 & 5.58 & 18 \\
\hline $2 \mathrm{C}$ & $46-58$ & silty clay loam & 28.4 & 50 & 5.96 & 9 \\
\hline $3 B \operatorname{tgb}$ & $58-81$ & silty clay & 42.5 & 66 & 5.69 & 11 \\
\hline $3 \mathrm{Cg}^{2}$ & $81-107+$ & silty clay & 25.2 & 86 & 5.83 & 10 \\
\hline \multicolumn{7}{|c|}{ Forest edge } \\
\hline$A$ & $0-10$ & sandy clay loam & 30.2 & 40 & 4.83 & 50 \\
\hline$A B$ & $10-23$ & sandy clay loam & 23.4 & 53 & 4.92 & 20 \\
\hline Bt1 & $23-41$ & sandy clay loam & 19.7 & 60 & 4.96 & 17 \\
\hline Bt2 & $41-66$ & Ioam & 18.2 & 83 & 5.25 & 7 \\
\hline $2 \mathrm{Btb}$ & $66-97$ & clay loam & 28.7 & 77 & 5.87 & 7 \\
\hline $2 \mathrm{Cg}^{2}$ & $97+$ & silty clay & nd & nd & nd & nd \\
\hline
\end{tabular}

${ }^{1} \mathrm{CEC}$ indicates cation exchange capacity; nd, not determined.

${ }^{2} \mathrm{Has}$ a varved (layered) depositional structure with occasional coarse strata

et al. 1984; Jacobs and Gilliam 1985; Johnston et al. 1990; Jordon et al. 1993; Pearce et al. 1998; Corley et al. 1999). The impact of grazing livestock on riparian ecosystems has caused considerable concern. Research addressing these concerns has been multifaceted but is centered on grazing-induced vegetational changes, decline in soil health, loss of biotic diversity, loss of fisheries habitat, reduced stream water quality, and changes in stream hydrology (Johnson et al. 1978; Leege et al. 1981; Platts 1981; Kauffman and Krueger 1984; Bohn and Buckhouse 1985; Siekert et al. 1985; Stuber 1985; Schultz and Leininger 1990; Popolizio et al. 1994; Belsky et al. 1999; Flenniken et al. 2001).

Although several studies have evaluated the effect of livestock grazing on nutrient runoff (Trlica et al. 2000; McEldowney et al. 2002), we were unable to find any studies that have examined the influence of livestock grazing or livestock exclusion on the chemistry of the soil solution. Moreover, few studies have addressed the influence of livestock grazing or exclusion on areal distribution of soil chemical properties in such spatially diverse habitats as riparian areas. We believe such a study is warranted given the potential impacts livestock grazing can impart to the soil system. Compaction and reduced redox potentials can increase solubility of Fe and Mn (Lindsay 1979; Clary 1995). Denitrification rates can rise with increased soil compaction leading to potential loss of $\mathrm{N}$ capital (Tillman and
Ball 1999). Grazing can stimulate $\mathrm{N}$ mineralization, which, depending on other factors, can lead to ecosystem $\mathrm{N}$ loss or retention (Seagle et al. 1992; Douglas et al. 2000). Our purpose was to measure the influence of livestock (cattle) grazing exclusion in a montane meadow on nutrient availability, emphasizing the chemistry of the soil solution, as related to floodplain position, year, month, and soil depth. Our working hypothesis was that livestock grazing would not affect the chemistry of the soil solution relative to ungrazed controls.

\section{MATERIALS AND METHODS}

\section{Site Characteristics}

This study is part of a larger collaboration on montane meadow grazing nutrition (Huber et al. 1995), native plant ecophysiology (Svejcar and Riegel 1998), and soil genesis and morphology (Blank et al. 1995). The study area is along the upper reach of Grizzly Creek, a tributary to Lake Davis and the Feather River, north of Portola, California (lat $39^{\circ} 55^{\prime} 225^{\prime \prime} \mathrm{N}$, long $\left.120^{\circ} 37^{\prime} 591^{\prime \prime} \mathrm{W}\right)$. Grizzly Creek is about $1 \mathrm{~m}$ in width, and the associated meadow ranges from about 150 to $500 \mathrm{~m}$ in width. The surrounding uplands are forested by lodgepole pine (Pinus contorta Louden ssp. murrayana [Grev. \& Balf.] Critchf.), white fir (Abies concolor [Gordon \& Glend.] Lindley), and Jeffrey pine (Pinus jeffreyi Grev. \& Balf.). The dominant vegetation on the meadow consists of Kentucky bluegrass (Poa pratensis L.), baltic rush (Juncus balticus Willd.), Nebraska sedge (Carex nebrascensis Dewey), and tufted-hairgrass (Deschampsia caespitosa [L.] Beauv.). The species composition changes systematically from stream edge to forest boundary; Nebraska sedge dominates very poorly drained areas along the stream, other graminoids increase in poorly drained midfloodplain positions, and forbs increase in the better-drained floodplain-upland interface.

Site elevation is approximately $1800 \mathrm{~m}$. At Three Mile Valley, approximately 5 miles south of the study site, average annual precipitation is $890 \mathrm{~mm}( \pm 340 \mathrm{SD})$, with the following amounts during the study period: $1989=1300,1990=400$, $1991=600,1992=560$, and $1993=940$. The soil temperature regime is frigid, and even during the summer months, early morning temperatures can be below freezing. The floodplain of Grizzly Creek, extending through Lake Davis, is mapped as Quaternary lacustrine deposits (Burnett and Jennings 1962). The geology of the surrounding area is complex. Adjacent uplands are mapped as Miocene, Oligocene, and Pliocene pyroclastics. Minor associated rock types include Miocene andesite and Mesozoic granodiorite. The upper reaches of Grizzly Creek are mapped as Paleozoic marine limestone and dolomite.

The meadow landscape has a complex pedogenic history (Blank et al. 1995). Soils are characterized by high organic surface layers overlying cambic horizons (Table 1). Over most of the meadow, the cambic horizons overlie lake-laid tephra layers. Beneath the tephra, there are high clay paleosol $\mathrm{Bt}$ horizons, which grade into gleyed and mottled lacustrine sediments. The soils are classified as Typic Humaquepts.

\section{Treatments}

Before establishment of the experimental pastures, the study site was 1 pasture of a 3 -pasture rotational grazing system and 
was grazed for approximately 2 weeks in each month of June, July, and August (Huber et al. 1995). In 1989, 9 pastures of 0.5-ha each, roughly containing equal proportions of streamedge, midfloodplain, and forest-edge vegetation communities, were fenced. Pastures were arranged as a randomized completeblock design with 3 treatments: no grazing (control); grazed to leave $1500 \mathrm{~kg} \cdot \mathrm{ha}^{-1}$ (low); and grazed to leave $1000 \mathrm{~kg} \cdot \mathrm{ha}^{-1}$ (moderate; this study used only control and moderately grazed plots). Nine $0.1-\mathrm{m}^{2}$ plots per pasture were clipped to determine use. Grazing treatments were short-term (1-14 days) at a high stocking density that achieved the study objectives. Treatments were initiated in 1990 and continued through 1993. Each year, turnout of cattle occurred when $P$. pratensis L. was in midbloom, which varied from late May to mid-July, depending on the depth of winter snow pack. In 1990 and 1991, treatments were applied using 30 cow-calf pairs; in 1990, paddocks were grazed for a 24-hour period on 9-10 July; in 1991, paddocks were grazed for 36 hours on 14-15 July. In 1992 and 1993, grazing was done by 14 steers: in 1992, from 22 May to 18 June; and in 1993, from 11 July to 11 August. Greater treatment details can be found in Huber et al. (1995).

\section{Lysimeter Installation and Sampling}

Lysimeters were constructed using 76-mm-diameter, 6.3-mmthick, porous ceramic plates with $10-\mu \mathrm{m}$ pore diameter (Coors Ceramics, Golden, CO). Plates were placed into machined nylon receptacles and epoxyed. Teflon tubing was threaded into a reservoir below the lysimeter plate to extract soil water. Lysimeters were installed in 2 control (excluded) and 2 moderately grazed paddocks at 3 landscape positions: forest edge, midfloodplain, and stream edge (see Table 1). Streamedge lysimeters were placed on the floodplain approximately $1 \mathrm{~m}$ from the channel edge. Midfloodplain lysimeters were located equidistant between the stream channel and the forest boundary in an area dominated by C. nebrascensis. Forest-edge lysimeters were located about $10 \mathrm{~m}$ from the forest boundary in an area dominated by J. balticus and forbs. Lysimeters were placed at 3 depths in the midfloodplain and forest-edge locations: at the bottom of the A horizon, directly atop the paleosol 3Btgb (midfloodplain) and 2Btb (forest edge) horizons, and in the gleyed $3 \mathrm{Cg}$ (midfloodplain) and $2 \mathrm{Cg}$ (forest edge) horizons at a depth of $1.2 \mathrm{~m}$. At the stream-edge location, lysimeters were placed at the bottom of the A horizon and at $0.6 \mathrm{~m}$ in gley and mottled $\mathrm{Cg}$ horizon. The stream-edge lysimeters were located closer to the stream than the soil described in Table 1, thus the difference in stratigraphy. In placing the lysimeters, we carefully excavated the soil so as to cover the lysimeter with similar stratigraphy. The 3 depths were all within one-half-meter horizontal distance of each other, and tubing was run beneath the ground to a central polyvinyl chloride (PVC) access tube.

Lysimeters were installed August 1989, and sampling began in December 1989. Lysimeter water was extracted using a hand vacuum pump, with the first few milliliters discarded. Because we did not pump the lysimeter for extended lengths of time, the soils were saturated or near saturation. Lysimeters were sampled periodically in 1990, 1991, 1992, and 1993. In most years, the soil was too dry to allow sampling of soil water after June. For this reason, we will report on lysimeter chemistry during months of April, May, and June, the months when most plant growth occurred during the study period.

\section{Bulk Soil Attributes}

In July 1991 and September 1993, bulk soils were sampled using a 7-cm-diameter bucket auger in the same control and moderately grazed paddocks in which lysimeters were installed. Samples were collected at stream-edge, midfloodplain, and forest-edge positions. In 1991, depths were 0-20, 20-40, and $40-60 \mathrm{~cm}$; in 1993, depths were 0-25 and 25-50 cm. Samples were air-dried in a glasshouse and lightly crushed to pass through a 2-mm sieve, homogenized, and stored in paper cartons until analyzed. Additional augered cores $(3$ replicates from each paddock, floodplain position, and depth) were taken in 1993 for root-length density (RLD). Homogenized subsamples were dispersed in hexametaphosphate, and roots were separated from the soil using a hydropneumatic elutriation (Gilson's Inc, Benzonia, MI). The length of fine roots was measured with a root-length scanner (Commonwealth Aircraft Corp, Melbourne, Australia). To remove the effect of debris and dead roots, a subsample of fine roots was manually counted for live roots and debris plus dead-root intersections using a $\times 10$-power binocular microscope. RLD was calculated from the total live-root length of the sample and the volume of soil that the roots occupied.

Soil electromotive potentials (redox) were quantified using 15-mm platinum wire, soldered on steel welding rods (Mueller et al. 1985). Two electrodes were placed between a PVC salt bridge to facilitate measurements under dry conditions. Potentials were read with a portable millivolt meter. Electrodes were placed at 2.5,20, and $50 \mathrm{~m}$ from the stream (stream edge, midfloodplain, and forest edge, respectively) in grazed and control treatments at a depth of $0.4 \mathrm{~m}$. The electrodes were read weekly throughout the growing season in 1990 and 1991.

\section{Laboratory}

Lysimeter samples were taken to the laboratory and kept refrigerated between analyses; all analyses were completed within 3 days of collection. Inorganic anions $\left(\mathrm{F}^{-}, \mathrm{Cl}^{-}, \mathrm{NO}_{2}{ }^{-}\right.$, $\mathrm{NO}_{3}{ }^{-}$, and $\mathrm{SO}_{4}{ }^{-2}$ ) and cations $\left(\mathrm{Na}^{+}, \mathrm{K}^{+}, \mathrm{Ca}^{+2}\right.$, and $\left.\mathrm{Mg}^{+2}\right)$ were filtered through $0.22-\mu \mathrm{m}$ nylon membranes and then quantified by ion chromatography (Dionex Corp, Sunnyvale, CA). Soil $\mathrm{pH}$ was measured with a glass electrode. Ortho-P was quantified by flow injection using molybdenum blue chemistry. Diethylenetriaminepentaacetate (DTPA, a metal chelator) extraction used the Lindsay and Norvell (1978) method, with extracted $\mathrm{Fe}, \mathrm{Mn}, \mathrm{Cu}$, and $\mathrm{Zn}$ quantified by atomic absorption spectroscopy. Bicarbonate extractable ortho-P was determined by the method outlined by Olsen and Sommers (1982), with quantification by flow injection using molybdenum blue chemistry. To extract $\mathrm{NO}_{3}{ }^{-}$and $\mathrm{NH}_{4}{ }^{+}, 30 \mathrm{~mL}$ of $0.5 \mathrm{M} \mathrm{KCl}$ solution was added to $10 \mathrm{~g}$ of soil and shaken for 30 minutes. Nitrate was quantified by ion chromatography and $\mathrm{NH}_{4}{ }^{+}$by membrane-diffusion flow injection.

\section{Statistical Analyses}

The experimental design was a randomized complete block. A variety of unbalanced factors for the lysimeter part of the 
experiment necessitated performing multiple analyses (SAS 1988). For lysimeter water collected above paleosol 3Btgb and $2 \mathrm{Btb}$ horizons, a 4-way analysis of variance (ANOVA) design was used, including treatment (grazed and excluded) and position (midfloodplain and forest edge), with repeated measures over years (1990, 1991, 1992, 1993), and months (April, May, and June). Lysimeter water collected in A and Cg horizons were evaluated with a 3-way ANOVA (preliminary analyses indicated year was not a significant factor), including treatment (grazed and excluded) and position (stream edge, midfloodplain, and forest edge), with repeated measures on months (April, May, and June). Duncan's New Multiple Range test was used as the multiple-comparison test for either an interaction or main effect when significant $(P \leq 0.05)$ ANOVA $F$ test results were obtained. For the bulk soil attributes measured, a 3-way, completely randomized ANOVA (treatment, position, and depth) was used. For a significant $F$ test, Fisher's Protected LSD was used to separate means.

\section{RESULTS}

\section{Lysimeter Data}

For lysimeter-extractable solutes obtained from A horizons, concentrations of $\mathrm{NH}_{4}{ }^{+}$and $\mathrm{NO}_{3}{ }^{-}$were influenced by significant treatment-by-landscape interactions. For the forest-edge position, grazing resulted in significantly lower $\mathrm{NH}_{4}{ }^{+}$(Fig. 1A) and significantly higher $\mathrm{NO}_{3}{ }^{-}$(Fig. 1B) than the corresponding excluded treatment. Overall, month of sampling had a large impact on many nutrients in lysimeter extracts, as illustrated by $\mathrm{K}^{+}$(Fig. $1 \mathrm{C}$ ).

For lysimeters placed above the paleosol Bt horizons (forestedge and midfloodplain positions), solution $\mathrm{SO}_{4}{ }^{-2}, \mathrm{~K}^{+}, \mathrm{Ca}^{+2}$, $\mathrm{Na}^{+}$, and $\mathrm{pH}$ all had significant treatment-by-landscape interactions. Grazed midfloodplain sites had significantly higher $\mathrm{SO}_{4}{ }^{-2}$ than corresponding livestock-excluded values (Fig. 1D). In the midfloodplain position, $\mathrm{K}^{+}$was higher in the grazed treatment, whereas for the forest-edge position, $\mathrm{K}^{+}$was higher on the excluded treatment (Fig. 1E). For the forest-edge lysimeters, the excluded treatment had significantly less $\mathrm{Ca}^{+2}$ (Fig. 1F) and $\mathrm{Na}^{+}$(Fig. 1G) than corresponding values for the grazed treatment. Solution $\mathrm{pH}$ was significantly higher on the grazed treatment but only for the forest-edge position (Fig. 1H).

For lysimeters placed in $\mathrm{Cg}$ horizons, there was a significant treatment-by-landscape interaction for $\mathrm{Mg}^{+2}$ and $\mathrm{Ca}^{+2}$. At the forest-edge position, the grazed treatment had significantly more $\mathrm{Mg}^{+2}$ (Fig. 1I) and $\mathrm{Ca}^{+2}$ (Fig. 1J) than the excluded treatment.

\section{Bulk Soil Attributes}

For soil measurements taken in July 1991, grazing had no effect on total soil $\mathrm{C}$, total soil $\mathrm{N}$, or soil C:N. The grazed treatment had significantly more bicarbonate-extractable ortho-P than the excluded treatment but only for the forest-edge position (Fig. 2A). For the same collection time, $\mathrm{KCl}$-extractable $\mathrm{NO}_{3}{ }^{-}$ and $\mathrm{NH}_{4}{ }^{+}$were very low, averaging $2.0 \mathrm{mg} \cdot \mathrm{kg}^{-1}$ for $\mathrm{NO}_{3}{ }^{-}$ and $4.0 \mathrm{mg} \cdot \mathrm{kg}^{-1}$ for $\mathrm{NH}_{4}^{+}$, with no significant treatment differences. DTPA-extractable Mn was significantly higher on the grazed treatment, but only at the stream-edge position, and overall DTPA Mn was much higher at stream-edge positions
(Fig. 2B). There was a trend toward higher DTPA-extractable Fe on grazed areas, which was most pronounced in the 20-30 $\mathrm{cm}$ soil depth increment (Fig. 2C).

For soil measurements taken in September 1993, there were no treatment (main or interaction) effects for bicarbonateextractable ortho-P. Potassium chloride-extractable $\mathrm{NO}_{3}{ }^{-}$was significantly higher in the $0-25 \mathrm{~cm}$ depth increment of the grazed treatment compared with the corresponding excluded treatment (Fig. 2D). DTPA-extractable Zn was significantly lower in the grazed treatment but only at the midfloodplain position (Fig. 2E). There were no significant treatment effects, irregardless of landscape position, for DTPA-extractable Mn (Fig. 2F).

There was considerable variation among replicates for soil redox status (Fig. 3). In 1990, the grazed forest-edge treatment had higher redox status from June through early July than the excluded forest-edge treatment. Similarly, from late May through early July 1991, the grazed stream-edge position had higher redox values than the excluded stream-edge position.

RLD was not significantly influenced by treatment (Fig. 4). All stream positions had similar RLDs in the $0-25 \mathrm{~cm}$ depth increment; however, the decline in RLD from the $0-25 \mathrm{~cm}$ to $25-50 \mathrm{~cm}$ depth increment was much higher from midfloodplain and forest-edge positions.

\section{DISCUSSION}

Grazing treatments affected soil-solution chemistry, thus forcing rejection of our working hypothesis. Treatment differences in lysimeter-extractable solutes generally interacted with landscape position. Most grazing treatment effects occurred at the forest edge. Year and month of sampling did not significantly interact with treatment for any measured solute in lysimeter extracts. Moreover, livestock grazing did affect the bicarbonateextractable pool of P, the DTPA-extractable pool of micronutrients, and the $\mathrm{N}$ availability, but the significance depended on the time of sampling. An explanation for these findings should account for the influence of livestock grazing on 1) landscape redistribution of elements via urine and feces; 2) compensatory plant growth; 3) the soil microbial community; 4) soil compaction; and 5) litter accumulation and its effect on soil temperature and soil mineralization.

Landscape redistribution of nutrients via grazing may partially explain elevated $\mathrm{Ca}^{+2}, \mathrm{Mg}^{+2}$, and $\mathrm{Na}^{+}$in the middle lysimeters and higher $\mathrm{Mg}^{+2}$ and $\mathrm{Ca}^{+2}$ in the deep lysimeters. The research of Huber et al. (1995), conducted concurrently with our study in 1992 and 1993, indicated that the majority of livestock grazing time was spent in midmeadow and streamedge positions because of higher forage production and a greater relative abundance of highly palatable C. nebrascensis. However, the forest-edge position, especially in 1993, received a greater proportion of loafing use (loafing is the sum of lying, watering, and standing behavior) (Huber et al. 1995). Although fecal or urine output was not quantified by landscape position, the higher loafing time spent at the forest-edge suggests that there may be a transfer of chemical elements from stream-edge and midfloodplain positions to the forest edge. Cattle had access in the paddocks to trace-mineral salts placed along the forest edge with composition of the following by weight 

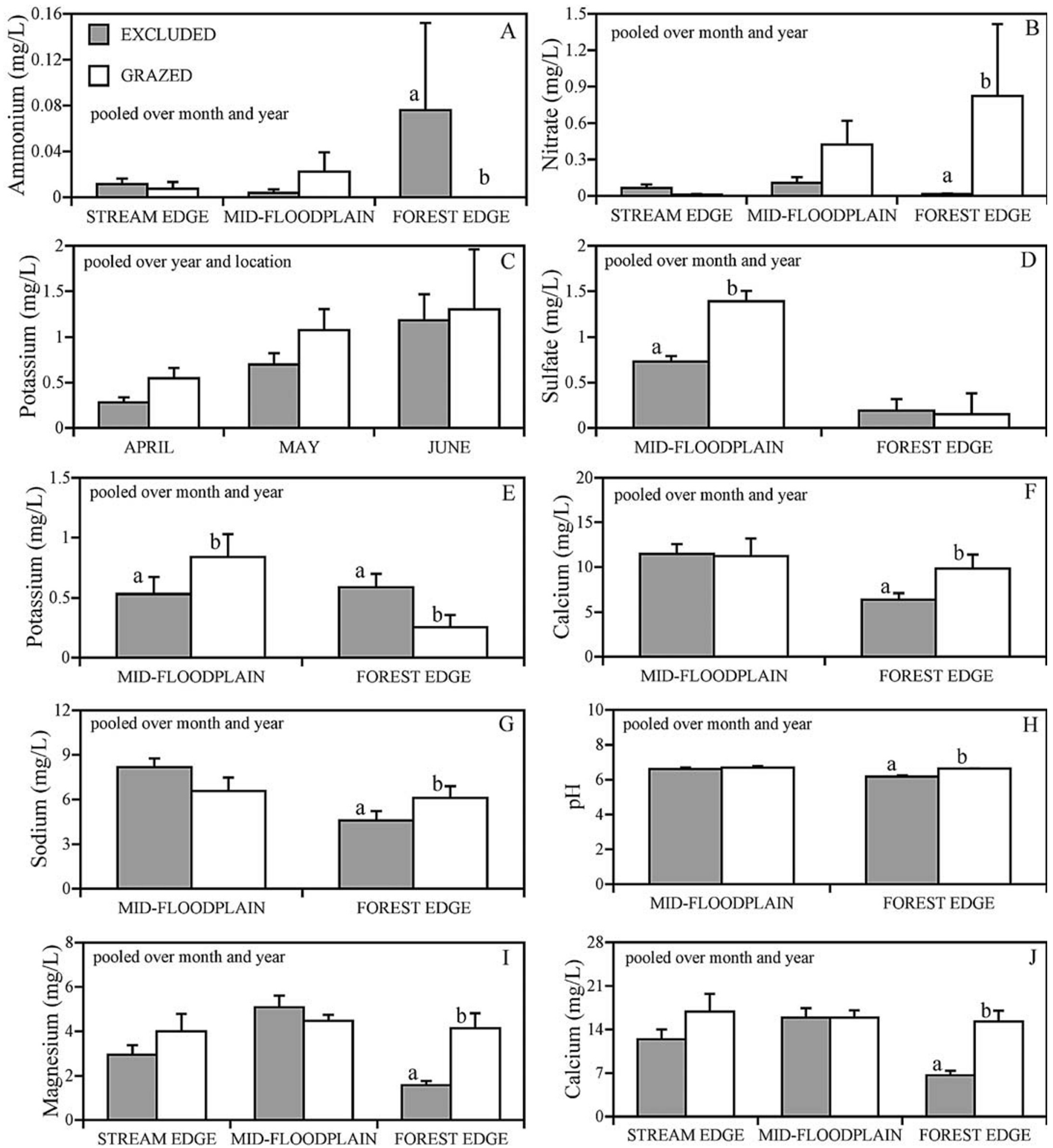

Figure 1. Influence of grazing and exclusion treatments on selected ionic species in lysimeter-extractable water. Bars are $1 \mathrm{SE}$. Data from panels are from the following lysimeter depths: A-C, A horizon. D-H, Top of paleosol Bt horizon. I-J, $\mathrm{Cg}$ horizon. For each panel, significant treatment differences for the specific floodplain location are denoted by different letters.

(\%): $\mathrm{NaCl}$ 97-99; Zn 0.85; $\mathrm{Mn} 0.22 ; \mathrm{Fe} 0.21 ; \mathrm{Mg} 0.10 ; \mathrm{Cu}$ 0.30; I 0.01; and Co 0.006 (Huber et al. 1995). The high content of $\mathrm{Na}$ in the salt blocks may be responsible for the higher content of $\mathrm{Na}^{+}$in the middle lysimeters of the grazed forest-edge position.
Lower $\mathrm{NH}_{4}{ }^{+}$and $\mathrm{K}^{+}$concentrations in lysimeter water from forest-edge grazed positions when compared with the excluded treatment, may be explained by stimulated plant growth in response to livestock grazing (McNaughton 1983; Boyd and Svejcar 2004). Greater plant growth in grazed treatments 

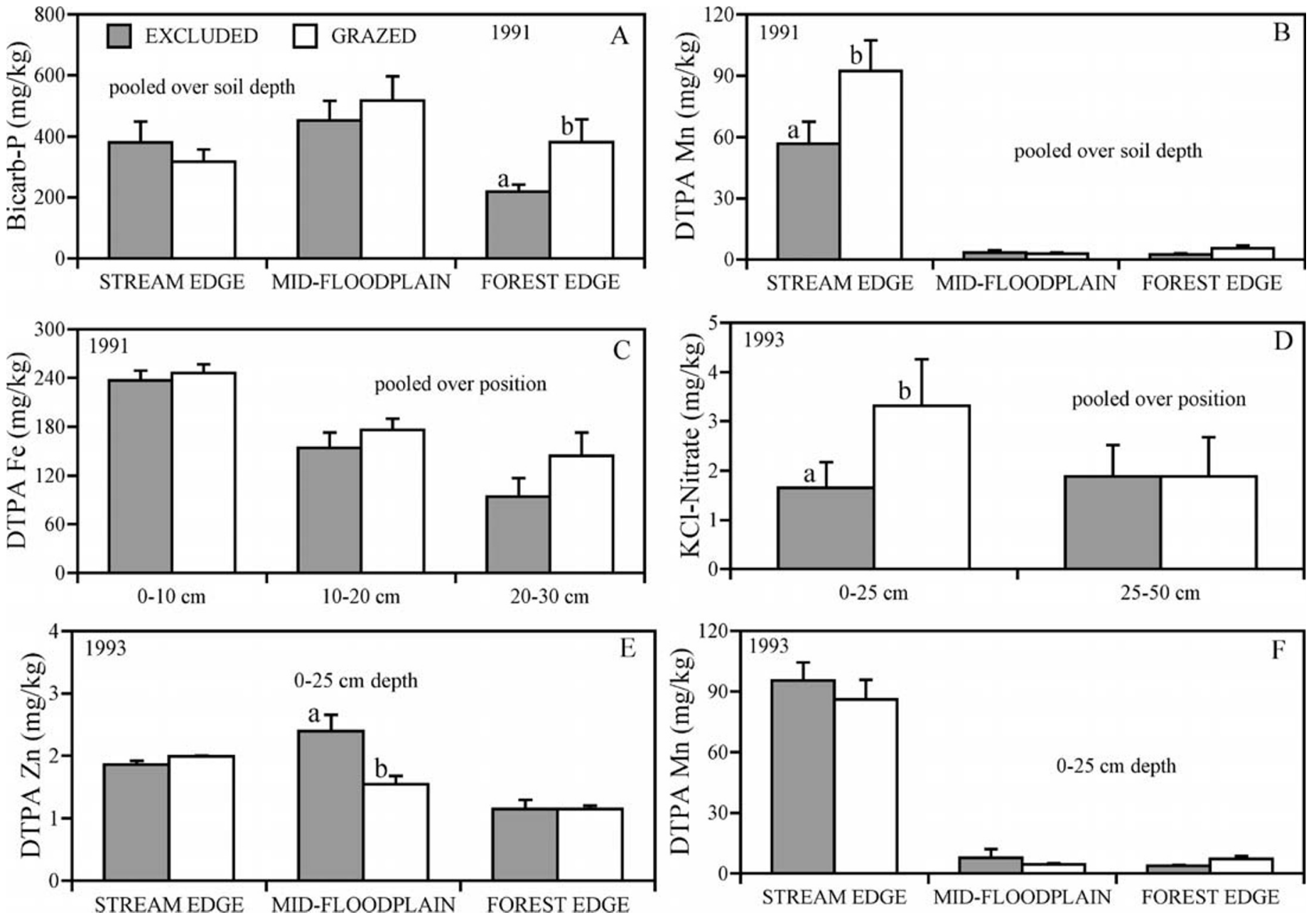

Figure 2. Selected soil attributes, measured in 1991 and 1993, showing relationships between grazed and excluded treatments. Bars are 1 SE. For each panel, significant treatment differences for a specific floodplain location or depth are denoted by different letters.

increases nutrient uptake and lowers lysimeter concentrations (Smit et al. 2002). Grazing increased lysimeter extractable $\mathrm{SO}_{4}{ }^{-2}$ and $\mathrm{NO}_{3}{ }^{-}$and increased $\mathrm{KCl}$-extractable $\mathrm{NO}_{3}{ }^{-}$in comparison with corresponding grazing-excluded treatments. $\mathrm{N}$ mineralization (Ruess and McNaughton 1987; Hearne and Howard-Williams 1988) and $\mathrm{N}$ and S cleaving-enzyme activity (Haynes and Williams 1999) may be stimulated by grazing. Elevated mineralization rates of $\mathrm{N}$ and $\mathrm{S}$ were apparently not balanced by higher root uptake of $\mathrm{NO}_{3}{ }^{-}$or $\mathrm{SO}_{4}{ }^{-2}$.

Soil measurements indicated that DTPA-extractable $\mathrm{Mn}$ and Fe were higher on the grazing treatment. Trampling action by livestock can compact soil and increase the soil's bulk density (Orr 1960; Laycock and Conrad 1967; Wheeler et al. 2002). Soil compaction can decrease soil aeration and increase the solubility of Mn and Fe (Lindsay 1979). Overall, there is no indication from our data that grazing caused a decrease in soil aeration relative to the excluded treatment. Soil redox measurements, however, showed that the grazed paddocks had higher aeration status than the control paddocks early in the season, which would argue for less, not more, $\mathrm{Mn}$ and Fe availability. We suspect that this grazing-induced increase in $\mathrm{Mn}$ and $\mathrm{Fe}$ availability may be the result of increased plant growth and elevated exudation of metal chelators (Fan et al. 2001).
Vegetation removal by livestock can increase soil temperatures (Chandler 1940). A potential effect of higher soil temperatures would be greater soil faunal activity, culminating in greater mineralization rates (Alexander 1977). Higher $\mathrm{SO}_{4}{ }^{-2}$ and $\mathrm{NO}_{3}{ }^{-}$concentration in the middle lysimeters of the grazed midfloodplain position and higher $\mathrm{KCl}$-extractable $\mathrm{NO}_{3}{ }^{-}$in the $0-25 \mathrm{~cm}$ depth increment of the grazed treatment may be partially explained in this manner.

A major mechanism of change once livestock are excluded is the accumulation of plant litter (Popolizio et al. 1994; Huber et al. 1995). Increased amounts of vegetation and litter forestall rising soil temperatures, thereby delaying plant phenological development and lowering early season mineralization rates (Sharrow and Wright 1977; Kauffman et al. 1983). This factor may explain the lower lysimeter-extractable $\mathrm{SO}_{4}{ }^{-2}$ on the grazing-excluded treatment.

The observed treatment differences may occur via mechanisms that are highly complex and little studied in riparian ecosystems. Soil mesofaunal and macrofaunal activity greatly influence the rate of litter decomposition and nutrient cycling (Coleman and Crossley 1995). Treatment differences in the numbers and species composition of such organisms may differentially influence nutrient mineralization rates. For some 

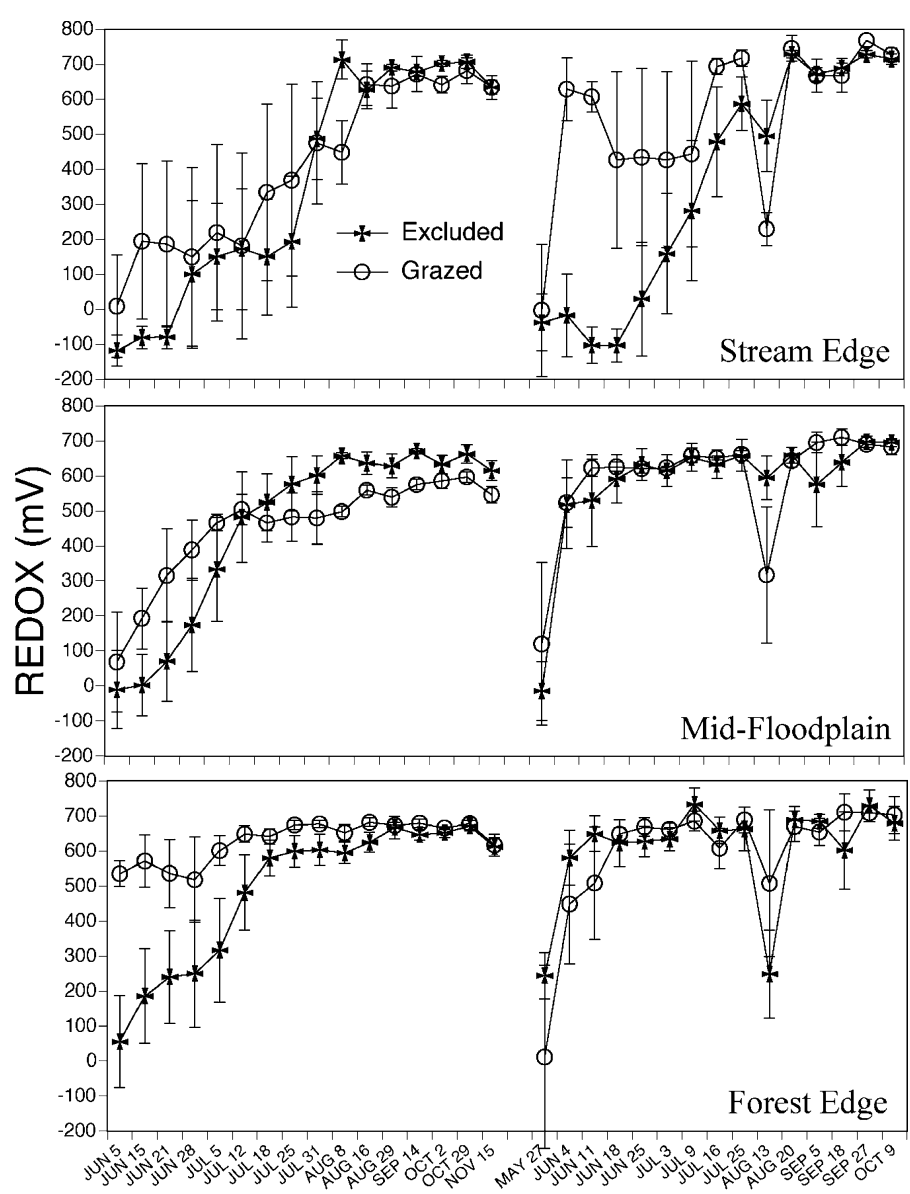

1990

1991

Figure 3. Seasonal trends in soil redox potential measured in 1990 and 1991 by landscape position and treatment. Bars are 1 SE.

plant species and communities, grazing can reduce root weight and root exploration (Klepper 1991). If livestock grazing causes root systems to explore less soil or not extend to as great a depth, reduced plant nutrient uptake and reduced vertical transfer of elements, when compared with ungrazed systems, could result. In the period of our study, however, there were no significant grazing effects on RLD. Our results confirm the findings of Manning et al. (1989) and Dwire et al. (2004) that meadow communities have very high RLDs (root biomass), which may explain the relatively low levels of available nutrients and high organic matter content of the riparian soil we studied.

Grazing led to an increase in the bicarbonate pool of extractable $\mathrm{P}$ only in the forest-edge position, and two factors may be involved. First, livestock manure can contain appreciable $\mathrm{P}$ (Moore and Willrich 1982), and grazing can concentrate $\mathrm{P}$ via animal watering areas and resting areas (West et al. 1989). We hypothesize that loafing time spent near the forest edge (Huber et al. 1995) can increase pools of soil P via transfer from stream-edge and midfloodplain positions. Second, increased aboveground plant growth in response to herbivory may be involved. Elevated growth may stimulate root exudation of organic acids, which might release $\mathrm{P}$ chemisorbed on metal oxides (Shen et al. 2002).

A plausible mechanism to explain grazing-induced increases in soil $\mathrm{pH}$ at the forest-edge location involves elevated de-

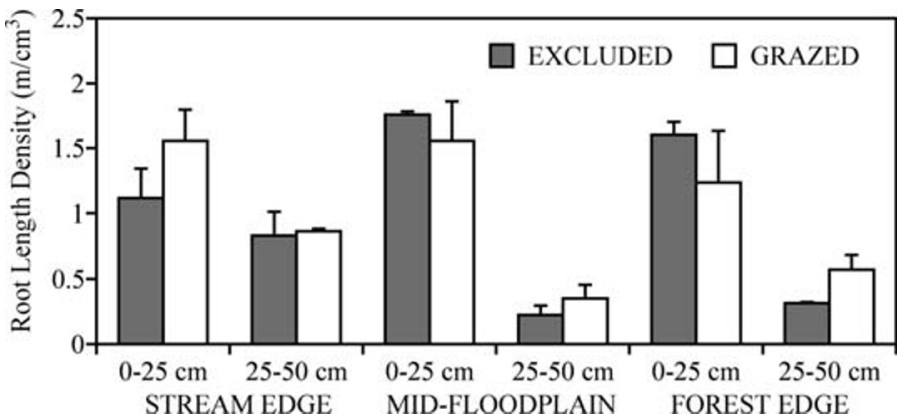

Figure 4. Root length density by treatment, soil depth, and floodplain position. Bars are $1 \mathrm{SE}$.

position of cattle urine on the forest-edge site. Somda et al. (1997) measured significant increases in soil $\mathrm{pH}$ with cattle urine deposition.

Any analysis of nutrient cycling in riparian systems must account for the impact of landscape positions. In our study, we included a steep gradient from the mesic stream-edge to the much drier forest-edge location. Grazing appears to impact soil-solution chemistry primarily at the forest-edge locations and mainly for $\mathrm{N}$. We found that both extractable soil $\mathrm{N}$ and soil-solution $\mathrm{N}$ were very low for all treatment and location combinations. In a study of soil-solution $\mathrm{N}$ dynamics in a Colorado montane meadow, Stednick and Fernald (1999) found very low solution concentrations of $\mathrm{NH}_{4}{ }^{+}$and $\mathrm{NO}_{3}{ }^{-}$and concluded that their riparian area was generally a sink for $\mathrm{NO}_{3}{ }^{-}$. We did not quantify water movement, but we suspect that dilution of the soil solution would be more important at the stream edge than at the forest edge.

\section{MANAGEMENT IMPLICATIONS}

Results of our research are most applicable to native, wet meadows of the Sierra Nevada because the lack of multiple stream replications limits conclusions about wider geographic areas. These montane meadows maintain very high RLDs when grazed at moderate levels. Vigorous rooting activity and nutrient uptake by riparian plant communities in good condition will ensure that readily available soil nutrients are sequestered in plant tissue during the growing season, lessening the possibility of stream water degradation. Moderate grazing had minimal impacts on the composition of the dominant species (G. Riegel, unpublished data). If grazing was severe enough to cause a shift to species with a lower rooting density or to a root system less adapted to flooded conditions, then impacts on soil-solution chemistry would seem more likely. We suggest that the management goal in these riparian meadows should be to ensure that the well-adapted species with high RLDs are favored.

\section{ACKNOWLEDGMENTS}

We thank Chad Boyd and anonymous reviewers for helpful criticisms and Ms Fay Allen for field and laboratory assistance. 


\section{LITERATURE CITED}

AleXAnder, M. 1977. Introduction to soil microbiology. New York, NY: John Wiley and Sons. $467 \mathrm{p}$.

Belsky, A. J., A. Matzke, and S. Uselman. 1999. Survey of livestock influences on stream and riparian ecosystems in the western United States. Journal of Soil and Water Conservation 54:419-431.

Blank, R. R., T. Svejcar, and G. Riegel. 1995. Soil genesis and morphology of a montane meadow in the northern Sierra-Nevada range. Soil Science 160:136-152.

Bohn, C. C., AND J. C. Buckhouse. 1985. Some responses of riparian soils to grazing management in northeastern Oregon. Journal of Range Management 38:378-381.

Boyd, C. S., AND T. J. SveJcAR. 2004. Regrowth and production of herbaceous riparian vegetation following defoliation. Journal of Range Management 57: 448-454.

Burnett, J. L., And C. W. Jennings. 1962. Geologic map of California-Chico Sheet. Sacramento, CA: California Division of Mines and Geology.

ChandleR, R. F., JR. 1940. The influence of grazing upon certain soil and climatic conditions in farm woodlands. Journal American Society of Agronomy $32: 216-230$

CLARY, W. P. 1995. Vegetation and soil responses to grazing simulation on riparian meadows. Journal of Range Management 48:18-25.

Coleman, D. C., and D. A. Crossley, JR. 1995. Fundamentals of soil ecology. San Diego, CA: Academic Press. 205 p.

Corley, C. J., G. W. Frasier, M. J. Trlica, F. M. Smith, and E. M. Taylor, Jr. 1999 Nitrogen and phosphorous in runoff from two montane riparian communities. Journal of Range Management 52:600-605.

Douglas, F. A., P. M. Groffman, E. R. David, and T. F. Benjamin. 2000. Ungulate stimulation of nitrogen cycling and retention in Yellowstone Park grasslands. Oecologia 123:116-121.

Dwire, K. A., J. Boone Kauffmam, E. N. Jack Brookshire, and J. E. Baham. 2004. Plant biomass and species composition along an environmental gradient in montane riparian meadows. Oecologia 139:309-317.

Fan, T. W. M., A. N. Lane, M. Shenker, J. P. Bartley, D. Crowley, and R. M. HIGASHI. 2001. Comprehensive chemical profiling of gramineous plant root exudates using high-resolution NMR and MS. Phytochemistry 57: 209-221.

Flenniken, M., R. R. McEldowney, W. C. Leininger, G. W. Frasier, and M. J. Trlica. 2001. Hydrologic responses of a montane riparian ecosystem following cattle use. Journal of Range Management 54:567-574.

HaYnes, R. J., AND P. H. Williams. 1999. Influence of stock camping behaviour on the soil microbiological and biochemical properties of grazed pastoral soils. Biology and Fertility of Soils 28:253-258.

HeARNE, J. W., AND C. HowaRD-Williams. 1988. Modeling nitrate removal by riparian vegetation in a spring fed stream: the influence of land-use practices. Ecologic Modeling 42:179-198.

Huber, S. A., M. B. Judkins, L. J. Kryst, T. J. Svejcar, B. W. Hess, and D. W. HoLCOMBE. 1995. Cattle grazing in a riparian mountain meadow: effects of low and moderate stocking density on nutrition, behavior, diet selection, and plant growth response. Journal of Animal Science 73:3752-3765.

JACOBS, T. C., AND J. W. GILLIAM. 1985. Riparian losses of nitrate from agricultural drainage waters. Journal of Environmental Quality 14:472-478.

Johnson, S. R., H. L. GaRY, AND S. L. Ponce. 1978. Range cattle impacts on stream water quality in the Colorado front range. Fort Collins, CO: USDA-Forest Service Research Note RM-359. 8 p.

Johnston, C. A., N. E. Detenbeck, and G. J. Niemi. 1990. The cumulative effect of wetlands on stream water quality and quantity: a landscape approach. Biogeochemistry 10:105-141.

Jordon, T. E., D. L. Correll, and D. E. Weller. 1993. Nutrient interception by a riparian forest receiving inputs from adjacent cropland. Journal of Environmental Quality 22:467-473.

Kauffman, J. B., W. C. Krueger, and M. Vavra. 1983. Effects of late season cattle grazing on riparian plant communities. Journal of Range Management 36:430-434.
Kauffman, J. B., and W. C. Krueger. 1984. Livestock impacts on riparian ecosystems and streamside management implications-a review. Journal of Range Management 37:430-437.

KLEPPER, B. 1991. Root-shoot relationships. In: Y. Waisel, A. Eshel, and U. Kafkafi [EDS.]. Plant roots, the hidden half. New York, NY: Marcel Dekker, Inc. p 265-286.

Laycock, W. A., And P. W. ConRad. 1967. Effect of grazing on soil compaction as measured by bulk density on a high elevation cattle range. Journal of Range Management 20:136-140.

Leege, T. A., D. L. Herman, and B. Zamora. 1981. Effects of cattle grazing on mountain meadows in Idaho. Journal of Range Management 34:324-328.

LINDSAY, W. L. 1979. Chemical equilibria in soils. New York, NY: John Wiley and Sons. $449 \mathrm{p}$.

Lindsay, W. L., AND W. A. Norvell. 1978. Development of a DTPA soil test for zinc, iron, manganese, and copper. Soil Science Society of America Journal 42:421-428.

Lowrance, R., R. L. Todd, J. Fall, JR., O. Hendrickson, JR., R. Leonard, and L. Asmussen. 1984. Riparian forests as nutrient filters in agricultural watersheds. BioScience 34:374-377.

Manning, M. E., S. R. Swanson, T. Svejcar, and J. Trent. 1989. Rooting characteristics of four intermountain meadow community types. Journal of Range Management 42:309-312.

McEldowney, R. R., M. Flenniken, G. W. Fasier, M. J. Trlica, and W. C. Leininger. 2002. Sediment movement and filtration in a riparian meadow following cattle use. Journal of Range Management 55:367-373.

McNaughton, S. J. 1983. Compensatory plant growth as a response to herbivory. Oikos 40:329-336.

Moore, J. A., AND T. L. WILLRICH. 1982. Calculating the fertilizer value from manure from livestock operations. Corvallis, OR: Oregon State University Extension Service EC 1094.

Mueller, S. C., L. H. Stolzy, and G. W. Fick. 1985. Constructing and screening platinum microelectrodes for measuring soil redox potential. Soil Science 139:558-560.

Olsen, S. R., and L. E. Sommers. 1982. Phosphorus. In: A. L. Page [ed.]. Methods of soil analysis: No. 9 Agronomy. Madison, WI: Soil Science Society of America. p 403-430.

ORR, H. K. 1960. Soil porosity and bulk density on grazed and protected bluegrass range in the Black Hills. Journal of Range Management 13:80-86.

Pearce, R. A., G. W. Frasier, and M. J. Trlica. 1998. Sediment filtration in a montane riparian zone under simulated rainfall. Journal of Range Management 51:309-314.

PLATTS, W. S. 1981. Influence of forest and rangeland management on anadromous fish habitat in western North America-Effect of livestock grazing. Portland, OR: USDA-Forest Service, GTR PNW-124. 25 p.

Popolizio, C. A., H. Goetz, and P. L. Chapman. 1994. Short-term response of riparian vegetation to four grazing treatments. Journal of Range Management 47:48-53.

Ruess, R. W., ANd S. J. McNaughton. 1987. Grazing and the dynamics of nutrient and energy regulate microbial processes in the Serengeti grasslands. Oikos 49:101-110.

[SAS] Statistical Analysis Systems. 1988. SAS/STAT user guide, release 6.03. Cary, North Carolina: SAS Institute Inc.

Schulz, T. T., AND W. C. LeININGER. 1990. Differences in riparian vegetation structure between grazed areas and enclosures. Journal of Range Management 43: 295-299.

Seagle, S. W., S. J. McNaughton, and R. W. Ruess. 1992. Simulated effects of grazing on soil nitrogen and mineralization in contrasting Serengeti grasslands. Ecology 73:1105-1123.

Sharrow, S. H., AND H. A. Wright. 1977. Effects of fire, ash and litter on soil nitrate, temperature, moisture, and tobosa grass production in the rolling plains. Journal of Range Management 30:266-270.

Shen, H., X. L. Yan, M. Zhao, S. L. Zheng, and X. R. Wang. 2002. Exudation of organic acids in common bean as related to mobilization of aluminumand iron-bound phosphates. Environmental and Experimental Botany 48: $1-9$. 
Siekert, R. E., Q. D. Skinner, M. A. Smith, J. L. Dodd, and J. D. Rodgers. 1985. Channel response of an ephemeral stream in Wyoming to selected grazing treatments. In: Riparian ecosystems and their management: Reconciling conflicting uses. Fort Collins, C0: USDA-Forest Service GTR RM-120. p 276-279.

Smit, A., A. M. KoolJman, and J. SeviRK. 2002. Impact of grazing on litter decomposition and nutrient availability in a grass-encroached Scot pine forest. Forest Ecology and Management 158:117-126.

Somda, Z. C., J. M. Powell, and A. Bationo. 1997. Soil pH and nitrogen changes following cattle and sheep urine deposition. Communications in Soil Science and Plant Analysis 28:1253-1268.

Stednick, J. D., and A. G. Fernald. 1999. Nitrogen dynamics in stream and soil water. Journal of Range Management 52:615-620.

StUBeR, R. J. 1985. Trout habitat, abundance, and fishing opportunities in fenced vs. unfenced riparian habitats along Sheep Creek, Colorado. In: Riparian ecosystems and their management: Reconciling conflicting uses. Fort Collins, CO: USDA-Forest Service GTR RM-120. p 310-314.

Svejcar, T., AND R. G. Riegel. 1998. Spatial pattern of gas exchange for montane moist meadow species. Journal of Vegetation Science 9:85-94.
Tillman, R. W., and P. R. Ball. 1999. Grazing effects on denitrification in a soil under pasture during two contrasting seasons. Soil Biology and Biochemistry 31:903-912.

Trlica, M. J., E. A. Nibarger, W. C. Leininger, and G. W. Frasier. 2000. Runoff water quality from grazed and ungrazed riparian plots. In: P. J. Wiginngton, Jr. [ED.]. Proceedings AWRA International Conference on Riparian Ecology and Management in Multi-Land Use Watersheds; 28-31 August 2000; Portland, OR. Middleburg, VA: American Water Resources Association. p 699-701.

Warner, R. E., And K. M. Hendrix [eds.]. 1984. California riparian systems: Ecology, conservation, and productive management. Berkeley, CA: University of California Press.

West, C. P., A. P. Mallarino, W. F. Wedin, and D. B. Marx. 1989. Spatial variability of soil chemical properties in grazed pastures. Soil Science Society of America Journal 53:784-789.

Wheeler, M. A., M. J. Trlica, G. W. Frasier, and J. D. Reeder. 2002. Seasonal grazing affects soil physical properties of a montane riparian community. Journal of Range Management 55:49-56. 